\title{
Effect of Omega-3 On Orthodontic Tooth Movement: A Systematic Review
}

\author{
Siti Hardiyanti Nurhasanah', Gadis Meinar Sari ${ }^{2}$, Noengki Prameswari ${ }^{3}$ \\ ${ }^{1}$ Magister Program, Faculty of Medicine Airlangga University \\ 60132, Surabaya, East Java, Indonesia \\ 2Department of Physiology, Faculty of Medicine Airlangga University \\ 60132, Surabaya, East Java, Indonesia \\ ${ }^{3}$ Department of Physiology, Faculty of Dentistry Hang Tuah University, \\ 60111, Surabaya, East Java, Indonesia \\ *Corresponding author details: Gadis Meinar Sari; @gadis-m-s@fk.unair.ac.id
}

\begin{abstract}
Orthodontic movement is a continuous and balanced process characterized by resorption and apposition of bone in areas of pressure and tension after mechanical strength forces are applied. The purpose of this systematic review was to determine the effect of omega-3 administration on orthodontic tooth movement from various studies that have been carried out previously. Search articles online using PubMed, ProQuest, Scopus, Ebscohost, and Google Scholar between 1995-2021. The keywords used were (Orthodontic tooth movement OR Orthodontic movement AND bone remodelling OR Alveolar bone remodelling OR Alveolar remodelling AND Omega 3 OR Fatty acids OR EPA DHA). A total of 530 articles were obtained and then screened using titles, abstracts, and can access full text there are 44 articles. Then by using inclusion and exclusion criteria, three full-text journals were obtained and compiled using PRISMA. These studies show that omega-3 administration affects orthodontic tooth movement. Omega 3 can slow down the movement of orthodontic teeth so that it can consider as a method of preventing relapse by giving omega- 3 at the end of orthodontic treatment.
\end{abstract}

Keywords: orthodontics tooth movement; omega 3; bone remodeling; EPA DHA; arachidonic acid

\section{INTRODUCTION}

Orthodontic movement is a continuous and balanced process characterized by resorption and apposition of bone in areas of pressure and tension after mechanical strength forces are applied [1]. Alveolar bone remodelling is a key component of orthodontic tooth movement [2] consisting of two phases, the process of bone formation by osteoblast cells and bone resorption by osteoclastic cells [3]. The rate of bone resorption controls the rates of movement of the teeth, while the rate of bone formation determines the success of treatment [4]. The results of orthodontic treatment have the potential for instability that tends to return to its original position, this event is called relapse [5]. Relapsing after orthodontic treatment has the same process as orthodontic tooth movement [6].

Orthodontic relapsing is caused [7] by a long and unstable remodelling process [8]. The main regulators of the bone remodelling process during orthodontic tooth movement are three cytokines, IL-1 $\beta$, IL- 6 , and TNF- $\alpha$ [9]. Cytokines are extracellular signalling proteins that are directly involved in bone remodelling in inflammatory processes [10].

Omega 3 exhibits anti-inflammatory effects by lowering levels of pro-inflammatory cytokines and pro-inflammatory mediators. Omega-3 is a polyunsaturated fatty acid consisting of eicosapentaenoic acid (EPA), and docosahexaenoic acid (DHA) [11]. Essential fatty acids especially EPA and DHA have an influence on the bone remodelling process [12].
Therefore, the purpose of this study is to summarize from existing research journals the effects of omega-3 administration on orthodontic tooth movement can be considered as one of the alternatives to prevent relapsing.

\section{MATERIALS AND METHODS}

Search Strategy and Data Extraction

The strategy used to search for journals is to use four databases (PubMed, ProQuest, Scopus, Ebscohost) and one search engine (Google Scholar). Search journals using keywords typed using free text searching and Boolean logic "(orthodontic tooth movement AND bone remodelling AND omega 3 OR fatty acids OR EPA DHA)". The PICOS (Population, Intervention, Comparison, Outcome, and Study) framework to analyze problems in the selected journals [13] then PRISMA (Preferred Reporting Items for Systematic Review and MetaAnalyses) was used as a reference for implementing the research protocol $[14,15]$. Besides the criteria (Table 1), the selected journal can be opened full-text and has no conflict of interest.

\section{Study Selection}

Articles have obtained based on keywords were screened again based on the content of the abstract then analyzed using the inclusion and exclusion criteria contained in PICOS [16]. 
TABLE 1: Inclusion and exclusion criteria

\begin{tabular}{|c|c|c|}
\hline $\begin{array}{c}\text { PICOST } \\
\text { framework }\end{array}$ & Inclusion & Exclusion \\
\hline Population & Research on rodents & Research on primates and dogs \\
\hline Intervetion & $\begin{array}{l}\text { - Orthodontic appliances } \\
\text { - Omega } 3\end{array}$ & $\begin{array}{l}\text { - Tooth extraction, orthodontic surgery } \\
\text { - non-omega } 3\end{array}$ \\
\hline Comparison & $\begin{array}{l}\text { - Control group } \\
\text { - Treatment group (treatment } 3 \text { to } 14 \\
\text { days) }\end{array}$ & $\begin{array}{l}\text { - There is no control group } \\
\text { - Treatment duration is less than } 3 \text { days or more } \\
\text { than } 14 \text { days }\end{array}$ \\
\hline Outcome & Orthodontic tooth movement & Other data \\
\hline $\begin{array}{l}\text { Study design } \\
\text { \& publicaton type }\end{array}$ & $\begin{array}{l}\text { Randomied Controlled Trials (RCT), Quasi } \\
\text { experimental }\end{array}$ & $\begin{array}{l}\text { Systematic review/literature review article } \\
\text { review/book/thesis/case report }\end{array}$ \\
\hline Publishing year & $1995-2021$ & before 1995 \\
\hline Language & English & Other language \\
\hline
\end{tabular}

\section{Quality Assessment}

The JBI Critical Appraisal Tool is used to assess articles quality. Articles that use RCTs design for quality assessment will use a checklist from The JBI critical appraisal tool for RCTs while using quasi-experimental will use The JBI Critical Appraisal tool for quasiexperimental studies [17].
The assessment criteria that given a score of 'yes' or 'no' or 'unclear' or 'not applicable' and each criterion with a score of 'yes' will be a value of one point and the other scores were zero, each study score calculated and added up. The assessment score obtained is at least $50 \%$ for articles included in this systematic review [16]. In the last screening, the articles used in this study were just three because the score achieved was more than 50\% (Table 2).

TABLE 2: The JBI Critical Appraisal tool for RCTs and quasi-experimental studies

\begin{tabular}{|c|c|c|c|c|c|c|c|c|c|c|c|c|c|c|}
\hline & \multicolumn{13}{|c|}{ Criteria (RCTs) } & \multirow[t]{2}{*}{ Results } \\
\hline & 1 & 2 & 3 & 4 & 5 & 6 & 7 & 8 & 9 & 10 & 11 & 12 & 13 & \\
\hline \multirow[t]{3}{*}{ Ogrenim, et al [11] } & $\sqrt{ }$ & $\sqrt{ }$ & $\sqrt{ }$ & $\sqrt{ }$ & $\sqrt{ }$ & $\sqrt{ }$ & $\sqrt{ }$ & $\sqrt{ }$ & $\sqrt{ }$ & $\sqrt{ }$ & $\sqrt{ }$ & $\sqrt{ }$ & $\sqrt{ }$ & $\begin{array}{c}13 / 13 \\
(100 \%)\end{array}$ \\
\hline & \multicolumn{14}{|c|}{ Criteria (Quasi experimental) } \\
\hline & 1 & 2 & & 3 & 4 & & & 6 & & 7 & & 8 & 9 & \\
\hline Karunia,et al [18] & $\sqrt{ }$ & $\sqrt{ }$ & & $\sqrt{ }$ & $\sqrt{ }$ & & & $\sqrt{ }$ & & $\sqrt{ }$ & & $\sqrt{ }$ & $\sqrt{ }$ & $\begin{array}{c}9 / 9 \\
(100 \%)\end{array}$ \\
\hline $\begin{array}{l}\text { Iwami-Morimoto, } \\
\text { et al [19] }\end{array}$ & $\sqrt{ }$ & $\sqrt{ }$ & & $\sqrt{ }$ & $\sqrt{ }$ & & & $\sqrt{ }$ & & $\sqrt{ }$ & & $\sqrt{ }$ & $\sqrt{ }$ & $\begin{array}{c}9 / 9 \\
(100 \%)\end{array}$ \\
\hline
\end{tabular}

\section{Data Analysis}

Data analysis was done qualitatively.

\section{RESULTS}

The total data obtained based on keywords searched through databases and search engines was 530 articles from Google scholar, PubMed, ProQuest, Scopus, Ebscohost. Just three articles were selected for qualitative synthesis (systematic review).
PRISMA flow diagram shows in Figure 1. The articles were compared with each other shown in Table 3 . The three articles concluded that omega 3 slowed orthodontic tooth movement. Furthermore, the full texts of these articles were analyzed resulted in 3 journals that could be used in this systematic review (Figure 1) 


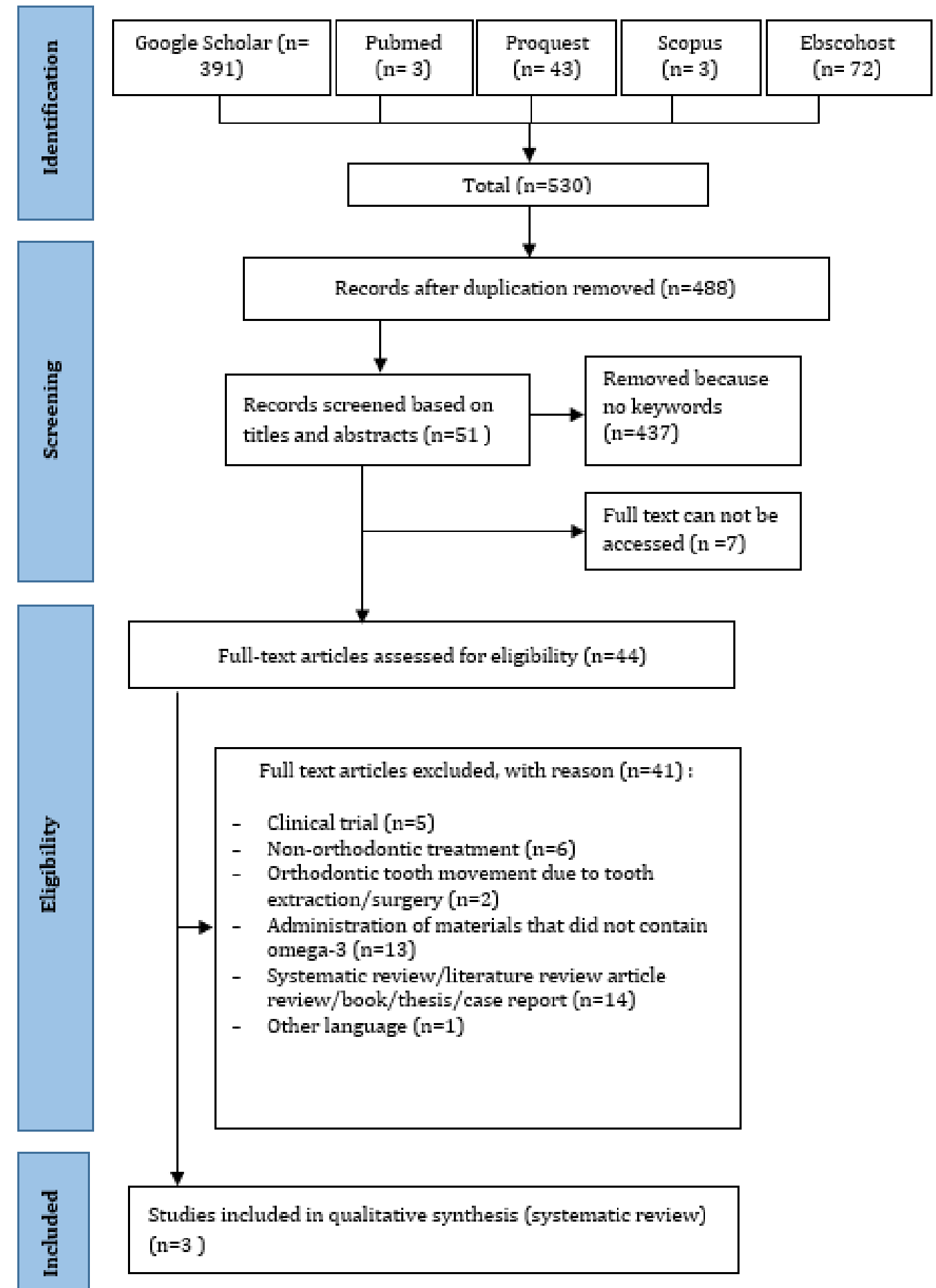

FIGURE 1: PRISMA flow diagram for this systematic review 
TABLE 3: Article comparison

\begin{tabular}{|c|c|c|c|c|c|c|c|c|c|}
\hline $\begin{array}{l}\text { Author \& } \\
\text { Year }\end{array}$ & Animal & Age & $\mathrm{N}$ & $\begin{array}{l}\text { Follow-up } \\
\quad \text { (days) }\end{array}$ & Group & $\begin{array}{l}\text { Orthodontic } \\
\text { appliance }\end{array}$ & $\begin{array}{c}\text { Omega } 3 \\
\text { Dose }\end{array}$ & $\begin{array}{l}\text { Orthodontic tooth movement } \\
\text { (OTM) }\end{array}$ & Conclusion \\
\hline \multirow{3}{*}{$\begin{array}{l}\text { (Karunia } \\
\text { et al, } \\
\text { 2019) } \\
\text { [11] }\end{array}$} & \multirow{3}{*}{$\begin{array}{l}\text { Males of } \\
\text { New } \\
\text { Zealand } \\
\text { rabbits }\end{array}$} & \multirow{3}{*}{$\begin{array}{c}\text { 6-8 } \\
\text { week } \\
\text { old }\end{array}$} & \multirow{3}{*}{15} & \multirow{3}{*}{$3,7,14$} & \multirow{3}{*}{$\begin{array}{l}3 \text { groups }(\mathrm{n}=5) \text { : } \\
\text { 1. Control group (OTM) } \\
\text { 2. DHA- } 750 \mathrm{mg} \text { group } \\
\text { 3. DHA- } 1500 \mathrm{mg} \text { group }\end{array}$} & \multirow{3}{*}{$\begin{array}{l}\text { Open coil } \\
\text { spring }\end{array}$} & \multirow{3}{*}{$\begin{array}{l}\text { DHA (750 mg } \\
\text { and } 1500 \mathrm{mg})\end{array}$} & Controls group (5.50 $\pm 0.21 \mathrm{~mm})$ & \multirow{3}{*}{$\begin{array}{l}\text { Dietary DHA } \\
\text { microalgae } \\
\text { inhibiting } \\
\text { orthodontic } \\
\text { tooth } \\
\text { movement } \\
\end{array}$} \\
\hline & & & & & & & & DHA- $750 \mathrm{mg}$ group $(4.80 \pm 0.14 \mathrm{~mm})$ & \\
\hline & & & & & & & & DHA-1500 mg group $(4.63 \pm 0.37 \mathrm{~mm})$ & \\
\hline \multirow[b]{2}{*}{$\begin{array}{l}\text { (Ogrenim } \\
\text { et al, } \\
2018) \\
{[18]}\end{array}$} & \multirow[b]{2}{*}{$\begin{array}{l}\text { Adult } \\
\text { male } \\
\text { Wistar } \\
\text { albino } \\
\text { rats }\end{array}$} & \multirow[b]{2}{*}{$\begin{array}{c}12 \\
\text { week } \\
\text { old }\end{array}$} & \multirow[b]{2}{*}{56} & \multirow[b]{2}{*}{$3,7,14$} & $\begin{array}{l}7 \text { groups }(n=8) \text { : } \\
\text { 1. Control group (without any treatment) }\end{array}$ & \multirow[b]{2}{*}{$\begin{array}{l}\text { Closed-coil } \\
\text { springs }\end{array}$} & \multirow[b]{2}{*}{$400 \mathrm{mg} / \mathrm{kg}$} & & \\
\hline & & & & & $\begin{array}{l}\text { Tooth movement groups } \\
\text { 2. tooth movement group for } 3 \text { days } \\
\text { 3. tooth movement group for } 7 \text { days } \\
\text { 4. tooth movement group for } 14 \text { days } \\
\text { Omega groups } \\
\text { 5. tooth movement and omega- } 3 \\
\text { administration group for } 3 \text { days } \\
\text { 6. tooth movement and omega- } 3 \\
\text { administration group for } 7 \text { days } \\
\text { 7. tooth movement and omega- } 3 \\
\text { administration group for } 14 \text { days }\end{array}$ & & & $\begin{array}{c}\text { Tooth movement group } \\
-3 \text { days }(0.369 \pm 0.072) \\
-7 \text { days }(0.323 \pm 0.109) \\
-14 \text { days }(0.501 \pm 0.099) \\
\text { Omega group } \\
-3 \text { days }(0.358 \pm 0.038) \\
-7 \text { days }(0.253 \pm 0.069) \\
-14 \text { days }(0.394 \pm 0.079)\end{array}$ & $\begin{array}{l}\text { Omega } 3 \text { fatty } \\
\text { acids could } \\
\text { decelerate } \\
\text { orthodontic } \\
\text { tooth } \\
\text { movement by } \\
\text { decreasing } \\
\text { the number of } \\
\text { osteoclasts }\end{array}$ \\
\hline \multirow{3}{*}{$\begin{array}{l}\text { (Iwami- } \\
\text { Morimot } \\
\text { o et al, } \\
1999) \\
\text { [19] }\end{array}$} & \multirow{3}{*}{$\begin{array}{c}\text { Male } \\
\text { Wistar } \\
\text { Strai rats }\end{array}$} & \multirow{3}{*}{$\begin{array}{c}4 \\
\text { week } \\
\text { old }\end{array}$} & \multirow[b]{3}{*}{60} & \multirow[b]{3}{*}{$0,3,7,14$} & $\begin{array}{l}\text { 8 groups: } \\
\text { Control group (diet containing } 10 \% \text { corn oil) } \\
(\mathrm{n}=30) \text { : } \\
\text { 1. } 0 \text { day }(\mathrm{n}=6)\end{array}$ & \multirow{3}{*}{$\begin{array}{l}\text { Lateral } \\
\text { expansion } \\
\text { spring }\end{array}$} & \multirow{3}{*}{$\begin{array}{l}\text { Purified diet } \\
\text { containing } \\
10 \% \text { refined } \\
\text { fish oil }\end{array}$} & $\begin{array}{l}\text { Day } 3 \\
\text { - Control group }(0.542 \pm 0.083 \mathrm{~mm}) \\
\text { - The amount of tooth movement was } \\
\text { slightly less in fish oil group }\end{array}$ & \multirow{3}{*}{$\begin{array}{l}\text { The amount of } \\
\text { tooth } \\
\text { movement in } \\
\text { the fish oil } \\
\text { group was } \\
\text { 80\% of that } \\
\text { seen than in } \\
\text { controls }\end{array}$} \\
\hline & & & & & $\begin{array}{l}\text { 2. } 3 \text { days }(\mathrm{n}=8) \\
\text { 3. } 7 \text { days }(\mathrm{n}=8) \\
\text { 4. } 14 \text { days }(\mathrm{n}=8)\end{array}$ & & & $\begin{array}{l}\text { Day } 7 \\
\text { Tooth movement in booth groups } \\
\text { progressed relatively slowly up to } 7 \text { days }\end{array}$ & \\
\hline & & & & & $\begin{array}{l}\text { Experimental group (diet containing } 10 \% \\
\text { refined fish oil) }(\mathrm{n}=30) \text { : } \\
\text { 5. } 0 \text { day }(\mathrm{n}=6) \\
\text { 6. } 3 \text { days }(\mathrm{n}=8) \\
\text { 7. } 7 \text { days }(\mathrm{n}=8) \\
\text { 8. } 14 \text { days }(\mathrm{n}=8)\end{array}$ & & & $\begin{array}{l}\text { Day } 14 \\
\text { - Control group }(1.082 \pm 0.170 \mathrm{~mm}) \\
\text { - Experimental group } \\
\text { The amount of tooth movement in the } \\
\text { fish oil group was significantly less than } \\
\text { in the controls ( } 82 \% \text { and } 80 \% \text { at } 7 \text { and } \\
14 \text { days, respectively) }\end{array}$ & \\
\hline
\end{tabular}




\section{DISCUSSION}

This systematic review aims to identify articles that conduct research on the effects of omega 3 on orthodontic tooth movement. Following a PRISMA assessment, the total number of articles obtained are three. Two articles are quasi experimental and one RCTs design studies, it was discovered after making a selection that omega 3 research in dentistry that met the inclusion criteria was very limited.

Table 3 shows the experiments were carried out in different periods. The difference in days is due to differences in the phases of tooth movement, consisting of the initial phase, lag phase, and post lag phase [20]. The initial phase usually occurs between 24 hours to 2 days [21]. The highest increase in tooth movement occurred between the 7th and 14th days which indicated the initial phase, then decreased between the 14 th and 28th days which showed the lag phase [22]. The Post lag phase is a phase where tooth movement occurs gradually or suddenly increases [23]. The tooth that has just been moved is surrounded by the newly formed osteoid bone. This uncalcified bone does not provide adequate stabilization of the teeth so contributes to relapse [24].

The use of different orthodontic appliances was also found in the articles studied, namely, in the research of Ogrenim et al [11] using closed-coil springs, in the study of Karunia et al [18] using open coil springs, while Iwami-Morimoto [19] lateral expansion springs, each device has a different function. Closed coil springs have a function as a space closure while opening coil springs are intended for opening space [25] while lateral expansion springs affect increasing the width of the dental arch and tooth spacing [26] research by Ogrenim et al [11] uses closed-coil springs, in Karunia et al [18] research uses open coil springs, while Iwami-Morimoto [19] lateral expansion springs, each device has different functions. Closed coil springs have a function as a space closure while opening coil springs are intended for opening space [25] while lateral expansion springs affect increasing the width of the dental arch and tooth spacing [26].
The doses of omega- 3 from the journals used as data in this study were different, Ogrenim et al [11] used omega 3 with the same dose for the treatment group $(400 \mathrm{mg} / \mathrm{kg})$, in the study Karunia et al [18] used different doses for the treatment group. DHA (750 mg and $1500 \mathrm{mg}$ ), while IwamiMorimoto et al [19] used pure fish oil. In a recent study conducted by Abou-Saleh et al [27], it was found that low doses of concentrated fish oil (CFO) with high EPA and DHA content can protect against bone loss compared to the use of high doses of regular fish oil. Fish oil-mediated beneficial effects on bone health are related to the concentration of $\mathrm{EPA}+\mathrm{DHA}$ supplements.

Table 3 also shows different orthodontic tooth movements between the control group compared to the group given omega 3. The key to tooth movement is changes in arachidonic acid levels that affect bone resorption [11]. Arachidonic acid produces eicosanoids that have a role in the inflammatory process. Eicosanoids are involved in modulating the intensity and duration of the inflammatory response [28]. Omega-3 enriched diet had an inhibitory effect on OTM. Omega-3 induced changes in arachidonic acid level in alveolar bone with accompanying changes in PG levels [29]. EPA contained in omega-3 also produces eicosanoids but has different properties from eicosanoids derived from arachidonic acid [28]. EPA can also act as a substrate for both cyclooxygenase (COX) and 5lipooxygenase (5-LOX), giving rise to eicosanoids with a slightly different structure from those formed from arachidonic acid (Figure 2) [30]. EPA and DHA also stimulate the formation of resolvin which has anti-

inflammatory properties. Resolvin D1 inhibits IL-1 production, and protectin D1 inhibits TNF and IL-1 $\beta$ production. The role of resolvin and related compounds is very important because it can stop the ongoing inflammatory process and limit tissue damage [28].

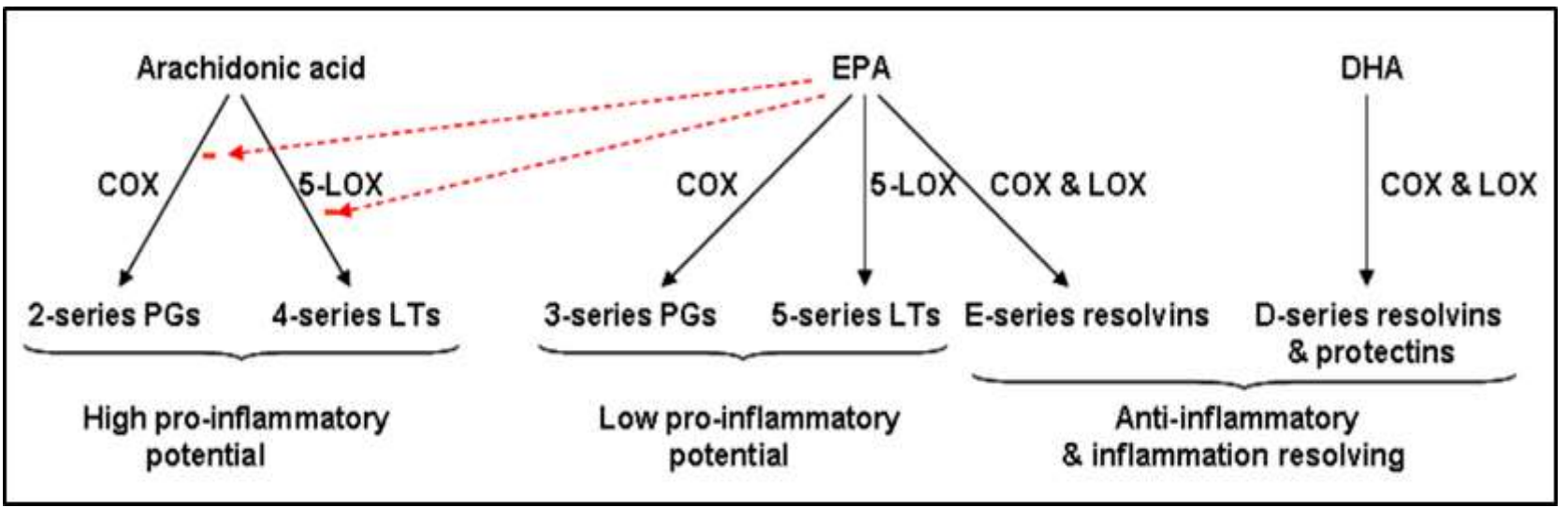

FIGURE 2: Overview of the synthesis and action of lipid mediators produced from arachidonic acid, EPA and DHA. COX, cyclooxygenase; LOX, lipoxygenase; LT, leukotrienes; PGs, prostaglandins [28].

\section{CONCLUSION}

The effect of giving omega-3 on orthodontic tooth movement showed that there was a slowing of tooth movement in the group that was given omega-3. In orthodontic treatment, giving omega-3 should be done at the end of orthodontic treatment.

\section{REFERENCES}

[1] D'Apuzzo F, Cappabianca S, Ciavarella D, et al. (2013). Biomarkers of periodontal tissue remodeling during orthodontic tooth movement in mice and men: overview and clinical relevance bone responses to orthodontic, The Scientific World Journal, 1-8.
[2] Li Y, Jacox LA, Little SH, et al. (2018). Orthodontic tooth movement: The biology and clinical implications, Kaohsiung Journal of Medical Science, 34,207-214.

[3] Siddiqui JA and Partridge NC. (2016). Reviews physiological bone remodeling: systemic regulation and growth factor involvement, American Physiological Society, (52): 233-245. International Journal of Scientific Advances ISSN: 2708-7972 
[4] Alikhani M, Alansari S, Sangsuwon C, et al. (2016). Biology of Orthodontic Tooth Movement: Current Concepts and Applications in Orthodontic Practice, Springer, Boston, 45-65.

[5] Elih. (2015). Relaps and retention after orthodontic treatment, Padjajaran Journal of Dentistry, 27(3):139148.

[6] Pudyani PS, Asmara W, Ana ID, et al. (2014). Alkaline phosphatase expression during relapse after orthodontic tooth movement, Dent. J. (Maj. Ked. Gigi), 47 (1), 25-30.

[7] Prameswari N, Brahmanta A, and Mulawarmanti D, (2018). Bone-immune interaction in osteogenesis relapse orthodontic after nanopowder stichopus hermanii application, Journal of International Dental and Medical Research, 11(1):323-329.

[8] Alhasyimi AA, Rosyida NF, Rihadini MS. (2019). Postorthodontic Relapse Prevention by Administration of Grape Seed (Vitis vinifera) Extract Containing Cyanidine in Rats, European Journal of Dentistry,13(4):629-634

[9] Vujacic A. (2018). Pavlovic J, Konic-Ristic A, The Role of Cytokines in Orthodontic Tooth Movement, IntechOpen, 4:35-49.

[10] Al-Ghurabi B, Al-Hindawi SH, Mohammad IS. (2020). Physiological Role of Immune System Elements in Orthodontic Treatment, Medico-legal Update. 20(4):119-121.

[11] Ogrenim G, Cesur MG, Onal T, et al. (2018). Influence of Omega -3 Fatty Acid on Orthodontic Tooth Movement in Rats: A Biochemical, histological, Immunohistochemical and Gene Expression Study, Orthodontics and Craniofacial Research, 22:24-31.

[12] Mangano KM, Sahnia S, Kerstetterb JE, et al. (2014). Polyunsaturated fatty acids and their relation with bone and muscle health in adults, NIH Public Access, 11(3):2-17.

[13] Methley AM, Campbell S, Chew-Graham C, et al. (2014). PICO, PICOS and SPIDER: a comparison study of specificity and sensitivity in three search tools for qualitative systematic reviews. BMC Health Serv Res, 14: 579 .

[14] PRISMA: Transparent Reporting of Systematic Reviews and Meta-Analyses, diunduh 1 Desember 2020, jam 07.31 wib, < http://www.prisma-statement.org/>.

[15] Moher D, Shamseer L, Clarke M, et al. (2015). Preferred Rreporting Items for Systematic Review and MetaAnalysis Protokols (PRISMA-P) 2015 Statement, BioMedCentral, 4 (1): 1-9.

[16] Nursalam, Kusnanto, Mishbahatul E, et al. (2020). Pedoman Penyusunan Literature dan Systematic Review, Unair, 1-111.
[17] The Joanna Briggs Institute. JBI: Critical Appraisal Tools. The University of Adelaide, download 01 Desember 2020, jam 01.23 wib, https://jbi.global/critical-appraisal-tools

[18] Karunia D, Sripudyani P, Mubarika S, et al. (2019). Effects of Docosahexaenoic Acid (DHA) Microalgae(R) on Orthodontic Tooth Movement in the New Zealand White Rabbit, Journal of International Dental and Medical Research, 12(4):1287-1292.

[19] Iwami-Morimoto Y, Yamaguchi K, Tanne K. (1999). Influence of Dietary n-3 Polyunsaturated Fatty Acid on Experimental Tooth Movement in Rats, The Angle Orthodontist, 69(4):365-371.

[20] Burstone C.J. (1962). The biomechanics of tooth movement. In: Kraus B.S., Riedel R.A., editors. Vistas in Orthodontics. Lea and Febiger; Philadelphia.

[21] Asiry MA. (2018). Biological aspects of orthodontic tooth movement: A review of literature, Saudi Journal of Biological Sciences. King Saud University, 25(6):027-1032.

[22] Baloul S, Gerstenfeld L, Morgan E, et al. (2011). Mechanism of action and morphologic changes in the alveolar bone in response to selective alveolar decortication-facilitated tooth movement. American journal of orthodontics and dentofacial orthopedics, Am J Orthod Dentofacial Orthop, 39(4 Suppl): S83-101

[23] Reddy SR, Singaraju GS, Mandava P, et al. (2015). Biology of tooth movement, Annals and Essences of Dentistry Review Article, vii (4):7-22.

[24] Gokhale SA, Byakod G, Gupta G, et al. (2015). Effects of laser aided circumferential supracrestal fiberotomy on relapse of orthodontically treated teeth: A pilot study, Journal of Dental Lasers, 9(1):16-22.

[25] Manhartsberger C \& Seidenbusch, W. (1996). Force delivery of Ni-Ti coil springs. American Journal of Orthodontics and Dentofacial Orthopedics, 109(1):821.

[26] Vania E, Zenab Y, Sunaryo IR. (2016). Kemajuan perawatan ortodontik dengan sekrup ekspansi rahang atas pada crowding ringan, Jurnal Kedokteran Gigi, 28(2):113-118.

[27] Abou-Saleh, Ouhtit A, Rahman MM. (2019). Bone Benefits of Fish Oil Supplementation Depend on Its EPA and DHA Content, MDPI: Nutrients, 11:2701.

[28] Calder PC. Omega-3 Fatty Acids and Inflammatory Processes, MDPI: Nutrients, 2010;2:355-374.

[29] Kokkinos PP, Shaye R, Alam BS, Alam SQ. (1993). Dietary lipids, prostaglandin E2 levels, and tooth movement in alveolar bone of rats. Calcif Tissue Int, 53:333-337.

[30] Kujur SK, Goswami V, Nikunj AM, Singh G, Bandhe S, Ghritlahre H. (2020). Efficacy of omega 3 fatty acid as an adjunct in the management of chronic periodontitis: A randomized controlled trial. Indian J Dent Res, 31:229-35 